\title{
Trends in Female Circumcision between 1933 And 2003 in Osun and Ogun States, Nigeria (A Cohort Analysis)
}

\author{
Lawrence A. Adeokun', Modupe Odunole', Frank Oronsaye', AO Gbogboade', Nurudeen Aliyu², Wumi Adekunle, \\ Grace Sadiq ${ }^{1}$, Ireti Sutton ${ }^{1}$, and Modupe Taiwo ${ }^{3}$
}

\begin{abstract}
The international movement against female circumcision gained momentum in the past two decades. Although recent studies report decline in the practice none has studied the cohort effect or provided plausible explanation for such decline. Changes in female circumcision occurring in two southwestern States of Nigeria between 1933 and 2003 were tracked in a cross-sectional survey using cohort analysis. 1174 female live births to 413 women were included in the analysis. About fifty-three percent of all females were circumcised. The prevalence dropped from $64.9 \%$ during the period $1933-60$ to $25.7 \%$ for the period $2000-2003$. For first order births, the corresponding rates were $58.8 \%$ and $25.0 \%$. The decline for first-born females comes a decade before other birth orders. Age and education of mother are two main factors of the decline. Global consensus or legal enforcement plays secondary roles. Understanding how modernisation affects the decline in female circumcision should receive greater attention. (Afr J Reprod Health 2006; 10[2]:48-56)
\end{abstract}

\section{RÉSUMÉ}

Tendances de l'excision féminine entre 1933 et 2003 dans les états d'Osun et Ogun au Nigéria (Une analyse cohorte). Le mouvement internationale contre l'excision féminine a gagné du terrain au cours de ces deux dernières décennies. Quoique les études récentes signalent une baisse par rapport à la pratique, aucune d'elles n'ont étudié ni l'effet cohort ni avancé une explication crédible pour un tel déclin. Les modifications à l'égard de l'excision féminine qui se produisent dans deux états du sud-ouest du Nigéria entre 1933 et 2003 ont été tracées dans une enquête tranversale à l'aide d'une analyse cohorte. Il y avaient 1174 naissances vivantes féminines pour 413 femmes qui ont fait partie de l'étude. 52, 4\% de toutes les femmes ont été excisées. La fréquence a chuté de 64, 9\% au cours de la période entre 1933 et 1960 à 25,7\% pour la période 2000 - 2003. Pour les naissances de premier ordre, les taux correspondants étaient de 58,8\% et 25,0\%. Le déclin par rapport aux premières nées femelles arrivent une décennie avant les autres ordres de naissance. L'âge et l'instructon de la mère sont deux facteurs qui expliquent le déclin. Le consensus global ou la mise en application légale joue un rôle secondaire. Il faut que la compréhension de la manière dont la modernization influe sur le déclin de l'excision feminine soit accordée une plus grande attention. (Rev Afr Santé Reprod 2006; 10[2]:48-56)

KEY WORDS: Female circumcision, first-born females, legal enforcement

${ }^{1}$ Association for Reproductive and Family Health, Ibadan, Oyo State, ${ }^{2}$ Sagamu Community Center, Shagamu, Ogun State, ${ }^{3}$ Live Vanguard, Osogbo, Osun State ${ }^{4}$ Inter African Committee (IAC) Nigeria on Harmful Traditional Practices Affecting the Health of Women and Children, Ogun State Chapter, Abeokuta, Ogun State

Correspondence: Prof. Lawrence Adeokun, Director, Evaluation and Operations Research Association for Reproductive and Family Health, 'ARFH HOUSE' Plot 815 A, Army Officers? Mess Road, Agodi G.R. A, Ikolaba, P.O.BOX 30259 Secretariat, Ibadan, Oyo State, Nigeria,Email: arfh@skannet.com.ng 


\section{Introduction}

Female Genital Mutilation or Cutting (FGM, FGC), which is also referred to as female circumcision, covers a range of procedures performed on the genitals of females of all different ages. ${ }^{1}$ Throughout history, human beings have mutilated and harmed their bodies in the name of culture, tradition, religion, beauty, health or social status. One of the most persistent forms of these physical violations is the mutilation of the genitalia. $^{2}$

Although the origin of FGM or when it first appeared is clouded, it has been reported in virtually all the continents of the world and is still being practiced, though with varying magnitude and increasing secrecy, despite well documented information about its medical and gynaecological implications and complications. Since the late 1980's a movement against female circumcision has emerged in Nigeria. The strength of that movement was drawn from involvement of Western-trained health activists including midwives and nurses ${ }^{3}$. Another factor that helped the profile of the movement was the strong association found between the severe forms of FGC and VVF especially in northern Nigeria. The movement also drew strength from the increasing international support and from the clear global mandate that came out from a number of landmark meetings in the early 1980s and 1990s, particularly Convention on the Elimination of all forms of Discrimination Against Women (CEDAW) in 1979, the International Conference on Population and Development (ICPD) in 1994 and the fourth World Conference on Women (1995). ${ }^{4}$

There are over 100 million girls and women who have undergone female genital mutilation (FGM) worldwide. ${ }^{5}$ In Africa, particularly in countries such as Nigeria, Ethiopia, Sudan and Egypt, FGM is widespread and a highly valued ritual practiced for various reasons. In some communities, it marks the transition from childhood to womanhood. It could be to reduce a woman's sexual desires or to ensure her virginity before marriage. Other communities consider female genitalia as ugly, offensive or dirty, and thus the removal of the external genitalia makes a woman more hygienic and aesthetically pleasing. Some subscribe to the notion that FGM enhances a woman's fertility and chances of her children?s survival. $^{5}$ A study amongst the Igbo tribes in Nigeria found that the Igbo woman believes that female genital circumcision makes them more feminine and thus more attractive to men. ${ }^{5}$

According to the World Health Organization (WHO), there are three types of FGM: type I or Clitoridectomy involves the removal of the clitoral hood, with or without removal of all or part of the clitoris; type II or Excision involves the removal of the clitoris, together with part of the labia minora. Type III or Infibulation or Pharaonic circumcision involves the removal of part or all of the external genitalia (clitoris, labia minora and majora), and stitching or narrowing of the vaginal opening, leaving a very small opening, about the size of the matchstick, to allow the flow of urine and menstrual blood. There is however a fourth type (Unclassified or introcision (which may involve pricking, piercing or incision of the clitoris and or labia; stretching the clitoris and or labia, cauterization by burning of the clitoris and surrounding tissues, scraping of the vaginal orifice or cutting of the vagina and introduction of corrosive substances into the vagina to tighten or narrow it. ${ }^{5-7}$ There is little evidence that type four FGM exist in Nigeria.

Depending on the timing and severity of FGM, the complications, which are well documented, could be very devastating and harmful to a woman throughout her life. It is difficult to determine the number of women who die from FGM related complications largely because of the highly secretive nature of the practice. Consequently, global efforts and legislations aimed at ending female genital mutilation especially in developing nations consistently pitch their arguments on medical complications and violation 
of the right of the girl child. Others view FGM as a barbaric Third World phenomenon.

Roughly $79 \%$ of circumcised women in Nigeria had the procedure in infancy. In Southwest, the proportion is higher. Of the four types of FGM practiced in Nigeria, the most common form is Type 1. Irrespective of the severity of the excision, the harmful effects of female circumcision provide the justification for its reduction and possible eradication. Such complications and side-effects include difficult urination, chronic pelvic infections, dyspareunia, and sexual dysfunction. Infibulation can also cause obstructed or prolonged labour, perineal tearing, and fetal distress. ${ }^{8}$

Recent studies have revealed a downward trend in the prevalence of FGM. In a survey conducted in the northern district of Ghana among a panel of women aged 15 to 49, 94 percent of the women aged 35 years and older reported being circumcised. This prevalence steadily decreased according to respondents' age. Among the youngest age group interviewed, those 15 to 19 years old, only 26 percent reported that they had being circumcised. ${ }^{9}$ In two recently published hospital based studies conducted in the southwest Nigeria, prevalence of the practice was determined to be 45 and 46 percent. $^{10,11}$ Both studies also found out that the prevalence of FGM decreased with decreasing age and increased with increasing age. In 2003, Jackson ${ }^{12}$ and others also reported in their study that decline in the prevalence of FGM is greatest among younger cohorts declining from 26 percent in 1995 to 8 percent in 2000. Caldwell et al. ${ }^{13}$ have reported a decline in the prevalence of FGM in Nigeria.

Although all these new studies reported a decline in the practice, none has looked at the cohort effect in trends or provided plausible explanation for such trends in decline. In this paper, changes in FGM occurring for each birth order in Osun and Ogun States in Southwest Nigeria from 1933 to 2003 was tracked in a cross-sectional survey using cohort analysis.
There are two ways of viewing change in, or persistence of traditional practices, including FGM. It does not matter if they are harmful or benign. One way is to view them as aspects of pre-modern societies and the other way is to view them as unintended targets or "victims" of modernisation. In the past, such practices were normative. They were not questioned. They were what everyone in the community did to belong. But as modernisation, operating through the twin agents of Religion and Education took hold, some practices became identified in the mind of converts and proselytes with conservatism or "backwardness". To be modern required that some of these practices be "left behind". Apart from FGM, breast-feeding is a clear example of a traditional practice falling victim to modernization of child rearing practices.

In interpreting the path of change too, recognition has to be given to momentous events that help mark turning point in the direction of change. It is within this framework for analysis of change that the trend in the circumcision of female children of various birth orders is carried out with data from two Yoruba states of Ogun and Osun in southwest Nigeria.

\section{Method}

A survey of 359 households in the two states produced interviews with 413 married females who had at least one life birth and 318 of their husbands. From the married females, a list of all children they had and their exposure to, and timing of various traditional practices was collected. The 413 women had a total of 2968 live births between them. 1,421 or $48 \%$ of these were female live births for which information on birth order, date of birth and the subsequent timing of female circumcision and a number of other traditional and invasive practices were provided. Only $6 \%$ of the female live births (247 cases) were of unknown dates and could not be included in the cohort analysis. Relying on the maternal reports of events is superior to self-

African Journal of Reproductive Health Vol. 10 No.2 August 2006 
report of events that may have taken place in childhood.

The information on the remaining 1,174 female live births forms the basis of the cohort analysis of the exposure of female children to childhood, mostly infant circumcision. This is the predominant type of FGM in Southwest Nigeria. Analysis was carried out for each birth-order and for all female children of all birth-orders combined. This approach allows inferences to be drawn from overall trends as well as from the information on first-born females. The significance attached to the circumcision of firstborn is within the more formal context in which Yoruba custom locates the first child. This is irrespective of the sex of child. Such children are said to "open the way". They are therefore given all the rites that the family can afford to give them. The implication is that the trend in the circumcision of female first born becomes, on its own, an important indicator of onset of change and how entrenched that change is. The experience of subsequent children will often take a cue from those of the first-born.

The period from 1933 to 2003 for which birth orders were reported was broken into periods reflecting changes in the socio-political history of the country. This arrangement also allows the aggregation into one period of the distant past, during which few cases are reported for individual years. The first period is from 1933 to 1960 when Nigeria became independent. The rest of the time is broken into decades with the exception of the open decade from 2001 to 2003 which can be treated on its own or lumped with the last decade of the $20^{\text {th }}$ century.

A vital global event with potential impact on the practice of FGM took place in late 1980s. In that period and subsequently, the United Nations and other international rights movements drew attention to the role of harmful traditional practice in the poor health status of women and children in the developing countries. Attention was paid to the harmful effects of FGM in particular. ${ }^{14-20}$
Another landmark event that set the period since 1990 to the present apart is the emerging link being made between some traditional practices and the risk of HIV infection. Female circumcision has been the most remarked of the risky childhood practices. ${ }^{21-24}$

Another methodological issue is the reliability of dating of events. As a result of nearly four decades of free primary education in southwest Nigeria (1955 -1983; 1999-2003), most parents are able to provide dates for vital events. The taking of birth histories is also a tested and proven method of generating data in less developing countries of Africa. ${ }^{25-26}$

Although the age at circumcision is not directly relevant to the cohort analysis, the fact that infant circumcision of type 1 is the predominant pattern in southwest Nigeria reduces the ambiguity of interpreting the data. The few who are reported as not circumcised are likely to stay that way. Whereas if the data was from some other region of the country, the adult timing of circumcision will make the information on current circumcision status unreliable basis of analysis of trends.

\section{Results}

Table 1 shows the percentage of female children of each birth order circumcised in the given cohorts from 1933 to 2003. From this information, a number of observations can be made about the overall pattern of female circumcision from cohort to cohort as well as changes occurring for each birth order.

First, the overall trend for the nine birth orders is that the proportion of all female children circumcised in the two project states, as represented by the communities in which the baseline survey was conducted, is just over half (52.4\%). This figure falls within the range that has been reported for the southwest region of Nigeria in other studies, raising confidence in the quality and robustness of the current data set. ${ }^{27}$ 
Table 1: Percentage of female children by parity at time periods 1933-2003

\begin{tabular}{|c|c|c|c|c|c|c|c|c|}
\hline \multirow{2}{*}{$\begin{array}{l}\text { Parity of female } \\
\text { child }\end{array}$} & \multicolumn{7}{|c|}{ COHORTS } & \multirow[t]{2}{*}{ Total } \\
\hline & $1933-1960$ & $1961-1970$ & $1971-1980$ & 1981-1990 & $1991-2000$ & $2001-2003$ & $\begin{array}{c}\text { Age } \\
\text { unknown }\end{array}$ & \\
\hline parity 1 & 58.8 & 67.7 & 76.7 & 48.3 & 29.9 & 25.0 & 53.1 & 49.1 \\
\hline parity 2 & 60.0 & 59.5 & 61.4 & 64.5 & 41.7 & 30.0 & 47.7 & 51.0 \\
\hline parity 3 & 66.6 & 55.5 & 69.2 & 64.4 & 50.0 & 16.0 & 48.6 & 54.4 \\
\hline parity 4 & 100.0 & 66.6 & 57.1 & 75.5 & 42.0 & 30.0 & 52.6 & 55.2 \\
\hline parity 5 & - & 60.0 & 52.9 & 82.0 & 42.8 & 15.3 & 35.5 & 51.8 \\
\hline parity 6 & - & 66.6 & 100.0 & 70.0 & 64.0 & 50.0 & 31.8 & 57.4 \\
\hline parity 7 & - & 75.0 & - & 85.7 & 47.6 & 0.0 & 46.0 & 47.8 \\
\hline parity 8 & - & 100.0 & 100.0 & 0.0 & 60.0 & 33.3 & 25.0 & 53.0 \\
\hline parity 9 & - & - & - & 75.0 & 66.6 & 100.0 & 57.1 & 68.2 \\
\hline $\begin{array}{l}\text { Total } \\
\text { Parity 1-9 }\end{array}$ & 64.9 & 64.9 & 66.3 & 69.4 & 43.6 & 25.7 & 45.3 & 52.4 \\
\hline
\end{tabular}

Second, from the 1933-60 to the 1981-90 cohorts around two-thirds of all female children were circumcised. This was followed by a sharp 26-percentage point decline in the 1991-2000 decade. In the short 3-year period of the current decade (2000-2003), the proportion circumcised is nearly halved to $25.7 \%$ of female children. The clear evidence of a downward trend in the circumcision of female children reflected for all birth orders is also reflected for individual birth orders. For example all birth orders, with the significant exemption of the first-born, show the onset of the decline at the 1981-90 decade.

Third, the timing of the decline for first-born females comes a decade before the decline for the other birth orders. This phenomenon has implications for the interpretation of the data. Two things mark the first birth order apart and each facilitates the adoption of innovation in general and in child rearing practices in particular. The proportion reporting the low birth orders will contain a number of women who are young and at the beginning of their child bearing. By the same token they will contain a number of mothers with small family sizes by choice. These are the educated women who have adopted family planning. It is no surprise that such women adopted the non-circumcision of female children earlier than other women. ${ }^{28-29}$
The fourth observation is that women reporting high birth orders are older. They are less well educated and more traditional in outlook than the young women. Consequently, they persist in traditional observances and practices than the younger women. In effect, age and education work together to differentiate the traditional older parents from the younger and more modern parents.

\section{Discussions}

There are a number of reservations that can be quickly laid to rest. A span of 70 years is a long time. But child bearing histories provided by women have been very robust in demographic analysis. ${ }^{30-32}$ There is certainly a case to be made that women are closer to these events and are emotionally attached to some of the events. Consequently, their accounts of childhood events are to be taken seriously even if those events took place more than half a century ago. Needless to say, those accounts are more reliable than reports of childhood events by the circumcised. Fortunately truncating the period of analysis to the forty years since independence does nothing to distort the downward trend that can be observed.

The next point of contention is the extent to which global events may be said to translate to

African Journal of Reproductive Health Vol. 10 No.2 August 2006 


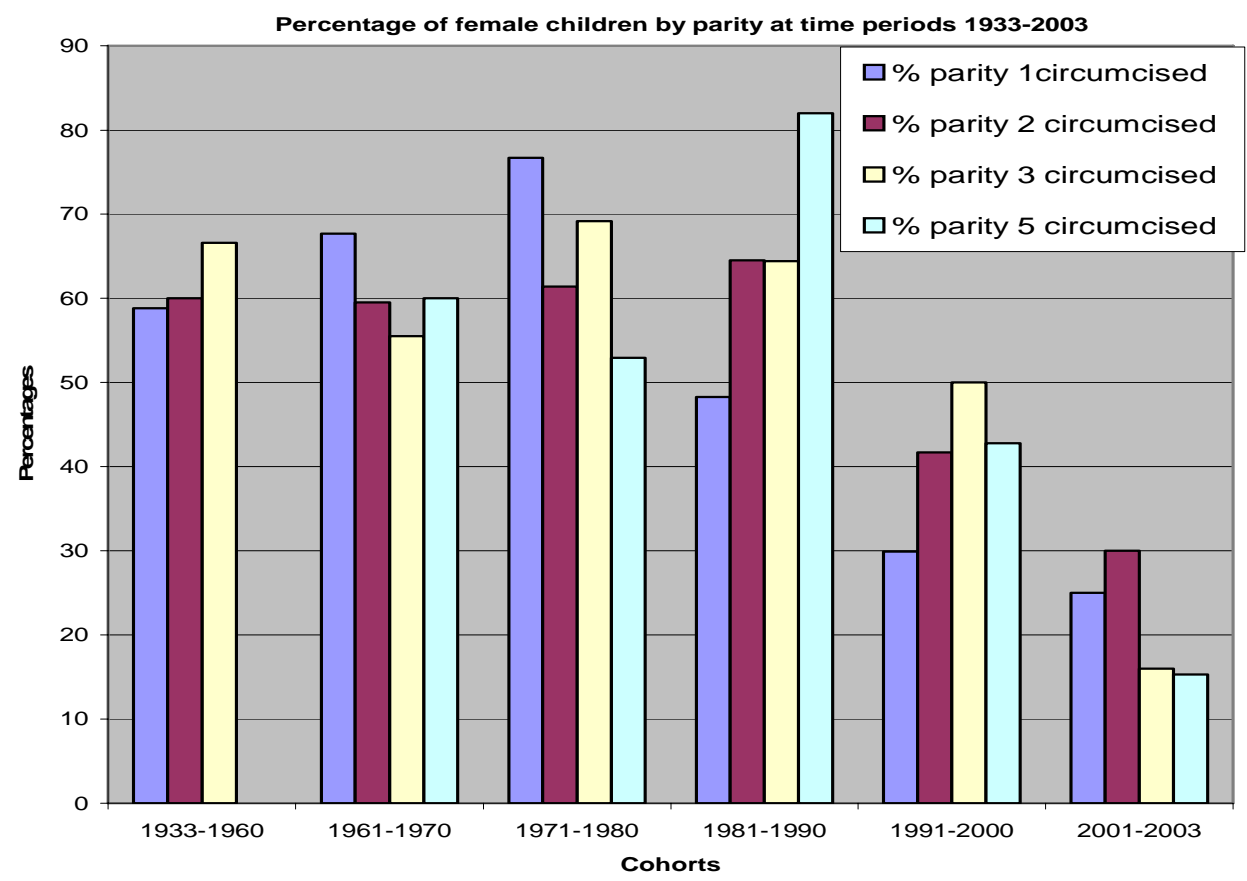

local events. It is tempting to take the sharp 26 percentage-point decline after the 1981-90 decade as an outcome of the global movement against FGC that gathered momentum in the late 1980s. However there is contradictory evidence from this baseline survey: A significant proportion of fathers cited that their stimulus for the discontinuation of the practice of female circumcision is coming from the mass media, health workers and government policies encouraging the discontinuation of the practice, whilst others claim non external stimulus such as weak socio-cultural basis for the practice, rising rate of formal education among women and increasing modernization of society as causing the practice of FGC to die out. ${ }^{26,31}$

Another issue of note is linked with the inevitability of change in a practice that is tied to another institution undergoing change. Traditional healers are needed to sustain circumcision. Their numbers are on the decline. That is, in spite of the efforts made in the past three decades about bringing traditional birth attendants into the health delivery system. There are now few women who rely solely on traditional healing or circumcising as their source of livelihood. Findings from this survey reveal that most have a primary occupation and practice traditional circumcising as a parttime activity.

Is this process of change irreversible so that drastic legislative measures are, in effect, coming too late? This may well be the case. There is a continuing hesitation in international circles about taking the legal root to abolition of female circumcision. A recent conference in Egypt involving some 20 odd nations concluded that such legalistic approach may not be acceptable and could well produce a backlash. ${ }^{33-34}$

\section{Conclusion}

One clear outcome of this analysis is that the decline in female circumcision was in place before the turning point of the global movement for its eradication. The most likely source of that downturn was the more insidious impact of modernization on child rearing practices in general and performance of traditional rites such as circumcision in particular. 
Another conclusion is that global movements go through the intermediation of government policies, awareness creation in the media and small scale and micro level efforts of NGOs before changes are effected in local communities. ${ }^{35,36} \mathrm{It}$ is the synergy between these supportive efforts that produce the shift in paradigm from what was normative to what is considered passé in terms of child rearing practices.

The observations from this analysis have implication for the implementation and outcomes of the use of participatory learning and action approach to the exploration of stakeholder perspectives on FGM. In such an approach, the pathways through which modernization operates to effect change in female circumcision and decision making about traditional rites should receive greater attention.

\section{REFERENCES}

1. United Nation Office for the Coordination of Humanitarian Affairs. When culture harms the girl - the globalization of female genital mutilation. IRIN News, 2005

2. Hutson JM. (2004) Circumcision: a surgeon's perspective. Journal of Medical Ethics 30: 238-40

3. Ezeh P (1990) Nigeria: female circumcision row. NEW AFRICAN (269): 28

4. Sonia Pressman Fuentes. Women?s Right movement: Where it?s been, Where it?s at. A keynote address to women layers of the State of Utah, United State. 2001

5. Brady M.(1999) Female Genital Mutilation: Complications and Risk of HIV Transmission. AIDS PATIENTS CARE AND STDs. 3 (12): 709716

6. Egwatu V, Agusa N(1981). Complications of female circumcision in Nigeria Igbos. British Journal of Obstetrics and Gynaecology 88:1090-1093

7. WHO (2004): Female Genital Mutilation Fact Sheets.

8. Anonymous, (1995) Female genital mutilation: a traditional rite that affects women's health. CONTRACEPTION REPORT. 6(1):12-3.
9. Mbacke, Cheikh, Phillip Adongo, Patricia Akweongo, and Fred N. Binka. (1998). Prevalence and correlates of female genital mutilation in the kassena-Nankana District of Northern Ghana. African Journal of Reproductive Health 2(2): 13-24

10. Larsen, Ulla and Friday Okonofua. (2002) "Female circumcision and obstetric complications." International Journal of Gynaecology and Obstetrics 77(2): 255-326

11. Snow, R.C., T.E Slamger, Friday E. Okonofua, F. Oronsaye, and J. Wacker. (2002). Female genital cutting in southern urban and peri-urban Nigeria: Self-reported validity, social determinants and secular trend decline. Tropical Medicine and International Health 7(1): 91-100.

12. Jackson, E.F, Akweongo P, Sakeah E, Hodgson A, Asuru R and Phillips JF.(2003) Women's Denial of Having Experienced Female Genital Cutting in Northern Ghana: Explanatory Factors and Consequences for Analysis of Survey Data. Population Council

13. Caldwell J.C; Orubuloye I.O; Caldwell P (2000) Female genital mutilation: conditions of decline. POPULATION RESEARCH AND POLICY REVIEW. June; 19 (3):233-54.

14. Marenah I. (1985) Events in the Gambia on traditional practices affecting the health of women and children in Africa since the Dakar conference held in February 1984. [Unpublished], 4 p.

15. Bulley, M. (1985) Workshop on Traditional Practices Affecting the Health of Women and Children in Africa at the Nairobi Conference on U.N. Decade for Women, July 1985. Female circumcision. [Unpublished] $3 \mathrm{p}$.

16. Population Action International (1993) Review of FGM projects supported by SPF / PAI. [Unpublished] [1993]4 p.

17. Odunjirin O, Akitoye CO, Oyediran M (1989) A Study on female circumcision in Nigeria. West African Journal of Medicine 8(3): 183-92

18. Kirberger, E.; Randolph K; Toubia, N. (1995) "The political and legal struggle over FGM in Egypt before and after the International Conference on Population and Development." In: Intersections between health and human rights: the case of female genital mutilation, by Elizabeth Kirberger, Kate Randolph, Nahid Toubia. New York, New African Journal of Reproductive Health Vol. 10 No.2 August 2006 
York, Research, Action and Information Network for Bodily Integrity of Women, 1995:10-7.

19. Haile Selassie A. (1995) International Conference on Population and Development, Cairo 5-13 September 1994 -- IAC presence. INTERAFRICAN COMMITTEE ON TRADITIONAL PRACTICES AFFECTING THE HEALTH OF WOMEN AND CHILDREN NEWSLETTER. April;(17):19

20. El Dawla, A.S (1999) The political and legal struggle over female genital mutilation in Egypt: five years since the ICPD. REPRODUCTIVE HEALTH MATTERS. 1999 May; 7(13): 128-36.

21. Pala O (1999) Girls at risk: The role of female circumcision in HIV transmission. PARTNER. 1999 Dec; 5(2): 3.

22. Kun, K.E (1997) Female genital mutilation: the potential for increased risk of HIV infection. INTERNATIONAL FEDERATION OF GYNECOLOGY AND OBSTETRICS. 1997 Nov; 59(2): 153-5.

23. Post MT (1995) Female genital mutilation and the risk of HIV. Washington, D.C., Academy for Educational Development, Support for Analysis and Research in Africa, 1995 May. [4], 9, [15] p. SARA Issues Paper

24. Johnson, K.E; Rodgers, S.(1994)When cultural practices are health risks: the dilemma of female circumcision. HOLISTIC NURSING PRACTICE. 1994 Jan;8(2):70-8.

25. Chidambaram VC; Cleland JG; Goldman N; Rutstein S (1992) An assessment of the quality of WFS demographic data. Source: In: The analysis of maternity histories, edited by Allan G. Hill and William Brass. Liege, Belgium, Editions DerouauxOrdina, 1992. : 183-215.

26. Gille H; van de Kaa DJ (1983) Contributions of the World Fertility Survey to survey methodology and analysis. Source: Voorburg, Netherlands, Netherlands Interuniversity Demographic Institute [NIDI], 1983. [21] p. NIDI Reprint Series no. 24

27. Nigeria Demographic and Health Survey (2003). National Population Commission Federal Republic of Nigeria.

28. Nkwo PE, Onah HE (2001) Decrease in female genital mutilation among Nigerian Ibo girls. INTERNATIONAL JOURNAL OF
GYNECOLOGY AND OBSTETRICS. Dec 2001; 75(3):321-2.

29. Sibanda A, Zuberi T (1999) In: Third African Population Conference, Durban, South Africa, 610 December 1999. The African Population in the 21 st Century. /Troisieme Conference Africaine sur la Population, La Population Africaine au 21e Siecle. Volume I, [compiled by] Union for African Population Studies. Dakar, Senegal, Union for African Population Studies 79-108

30. National Longitudinal Study of Youth, (1894) Ohio State University. Center for Human Resources Research, Columbus, Ohio, Ohio, State University, Center for Human Resources Research.

31. Encuesta de fecundidad (1987) Instituto Nacional de Estadistica, Madrid, Spain 928

32. Xasan DF (1989) Final resolutions. In: Female circumcision: strategies to bring about change. Proceedings of the International Seminar on Female Circumcision, 13-16 June 1988, Mogadisho, Somalia, [compiled by] Associazione Italiana Donne per lo Sviluppo [and] Somali Women's Democratic Organization. Rome, Italy, Associazione Italiana Donne per lo Sviluppo, 1989. : 121-5.

33. Kazeem, A. (1996) Female circumcision in OwuAbeokuta. YOUR TASK HEALTH MAGAZINE. 1996; 4(1): 22-4.

34. Raufu A (2002) Nigeria recommends jail terms to eradicate female genital mutilation. British Medical Journal. 2002 May 324(7345): 1056.

35. Orenuga F (1996) Collaboration with project "SISTER HELP". YOUR TASK HEALTH MAGAZINE. 1996; 4(1):26-7.

36. Adinma J (1997) Current status of female circumcision among Nigerian Igbos. West African Journal of Medicine 16(4) 227-231

\section{Acknowledgements}

The Baseline Survey of Stakeholders' Perspective on Female Genital Cutting was carried out by Association for Reproductive and Family Health (ARFH) in collaboration with the Sagamu Community Center (SCC), Sagamu, the InterAfrican Committee (IAC) Nigeria on Harmful Traditional Practices Affecting the Health of 
Women and Children, Ogun State Chapter, Abeokuta, and Live Vanguard, Osogbo, Osun State. Funding was received through Family Health International, USA.
Above all our gratitude goes to the people of Ijebu-Jesa, Ada, Ede and Kajola in Osun State, and the people of Ijagba, Sagamu, Soyindo, Epe, Gbagura, Ibara, Owu and Oke Ona, in Ogun State. Without their openness, the validity of this analysis would have been in serious doubt. 